\title{
The important role of academic leagues (extensions) in Brazilian medical education
}

1. University of São Paulo Medical School (FMUSP). Former president (2017) of the Brazilian Association of Medical Academic Leagues (ABLAM). São Paulo, SP, Brasil,. Junior Editor of the Revista da Associação Médica Brasileira (RAMB)

With a centennial history of success, academic extensions in Brazilian medical education stand for a major aspect of undergraduate students' knowledge. Their significant role in our medical schools and in our society started in 1920 with the "Liga de Combate à Sífilis" (in English, League for the fight against Syphilis) ${ }^{1}$ of the University of São Paulo Medical School. It established a cutting-edge change: from that moment, students could get together in groups under medical supervision, to offer assistance to those in need. It truly has altered paradigms in Brazilian health care.

A Medical Academic League or Extension (MAL) is a group of mainly undergraduate medical students that aim to study a subject according to the core values of the university ${ }^{2}$. Those students, with a common interest, can get together, invite a supervising physician, and develop essential skills based on learning, assistance, and research. Essentially, a MAL is an opportunity for students to be closer to their communities, being part of health promotion and social change processes, leading them to be better doctors and notably better citizens ${ }^{3}$.

There are some guiding principles for a MAL to help students improve their skills. As a matter of fact, without a basic set of principles, a group of students cannot even be called a league. Health education, advocacy, communication strategies, decision-making, and leadership are crucial features for a MAL to help build a highly-skilled physician integrated into a multi-professional team, which is precisely one of the things that can enhance the quality of health assistance in our country ${ }^{4}$. More importantly, being part of a MAL is not a mandatory activity. It shows self-motivation from the students to pursue a better education.

The European Academy of Teachers in General Practice and Family Medicine (EURACT) has listed seven essential roles for the medical professional ${ }^{5}$, and they all can be developed and exercised through the participation in a MAL: medical expert ${ }^{6}$ (evidence-based medicine discussions while offering assistance to the population); health advocate (being closer to the surrounding community can help understand their problems); manager ${ }^{7}$ (leadership skills are necessary for managing students who organize MAL activities); communicator (MAL helps students to communicate better with patients, peerto-peer communication and reporting their status to their supervisors); collaborator ${ }^{8}$ (working in a mul- 
tidisciplinary team); scholar (research and medical education are essential characteristics of a MAL); professional (exercising ethical assistance to the population).

MALs have a history of almost a hundred years of success in building better doctors and, in the end, making a better society since these health professionals can offer improved assistance for our pop- ulation. This country has serious issues when it comes to health services, especially in the public system. Nevertheless, MALs should be considered an innovative way to offer education for students and well-structured health care for the population in need. Therefore, medical schools should support this kind of initiative fomenting this path of citizenship access in Brasil.

\section{REFERENCES}

1. Burjato únior, Dacio; Sampaio, Sebastião Almeida Prado. História da liga de combate à sífilis e a evolução da sífilis na cidade de São Paulo (19201995). 1999.Universidade de São Paulo, São Paulo, 1999.

2. Mafra, S. Ligas acadêmicas. Diretórios Acadêmicos, v.2, n.7, 2006. Disponível em: <http://revista.cremepe.org.br/07/diretorios_academicos. php>. Acesso em: 7 out. 2008.

3. Torres Albina Rodrigues, Oliveira Gabriel Martins de, Yamamoto Fábio Massahito, Lima Maria Cristina Pereira. Ligas Acadêmicas e formação médica: contribuições e desafios. Interface (Botucatu) [Internet]. 2008 Dec; $12(27$ ): 713-720.

4. Bastos, M. L. S., Trajman, A., Teixeira, L. S., Belo, M. T. C. T. O papel das ligas acadêmicas na formação profissional. J Bras Pneumol. 38(6) p 80380.2012
5. Kersnik J. Primary care research and the training of family medicine teachers. The role of EURACT. In: Ministry of Health (Brazil). Challenges in the formation of primary care doctors in Brazil. Brasilia: 2007. p. $63-70$.

6. Torres MLA, Auler Jr JOC. Rev. Bras. Anestesiol. vol.62 no.1 Campinas Jan./ Feb. 2012

7. Hamamoto Filho, Pedro Tadao et al. Normatização da abertura de ligas acadêmicas: a experiência da Faculdade de Medicina de Botucatu. Rev. bras. educ. med. [online]. 2010, vol.34, n.1, pp.160-167. ISSN 01005502.

8. Kulkarni, D, Simon, $H$. The processes of scientific discovery: the strategy of experimentation. Cognitive Science 12, 139-175. 1988 